http://dx.doi.org/10.7833/116-1-1205

\title{
BEWARE OF THE (WESTERNISED) AFRICAN EYES: \\ REREADING PSALM 82 THROUGH THE VHUFA APPROACH
}

Hulisani Ramantswana

University of South Africa

\begin{abstract}
This article argues that the African eyes through which we are called to reread the Bible need to be decolonised on two fronts: First, our being African and being socially located in Africa does not automatically imply that we read through African eyes, so we must beware of Westernised African eyes. Second, the current postcolonial environment still retains structures of coloniality which continually destabilise Africa, so we must beware of Westernised Africa. The failure to decolonise African eyes leads to the reduplication of Western-European environments in our African context and the perpetuation of coloniality in our current environment. This article suggests the vhufa approach to reading of Scripture as a way of overcoming coloniality and as a way of bringing African knowledge systems to shape the reading of the biblical text. This approach is applied to Psalm 82 to highlight how the vhufa approach can be applied to reading of the biblical text.
\end{abstract}

Key Words: Westernised; Decolonisation; Coloniality; The Vhufa Approach; Psalm 82

\section{Introduction}

Given the history of colonialism and the colonisation of the African mind and the persistence of the structures of coloniality, my social location in Africa is a hybrid one. Being socially located in Africa does not automatically imply that one is thinking from an African epistemic location, nor does being black African or white African automatically imply that one is thinking from an African epistemic location. In my view, thinking from an African epistemic location is a task that is long overdue for African biblical scholars, given the violation and undermining of our African epistemology through Euro-Western paradigms. Thinking epistemically as Africans - or, to use Ukpong's words, "rereading through the African eyes" - calls us to overcome the colonial damage to the African mind and the resultant amnesia through remembering, preserving, utilising, and building on the great heritage left us by our African ancestors. ${ }^{1}$ A Tshivenda proverb comes to mind here, nyavhumbwa wa dagaila wa kanda vho u vhumbaho (You who are formed, you have become proud and trample over those who formed you.) The gist of this proverb is that people should not undermine their ancestors through whom they came into existence. Therefore, those of us whose knowledge systems were ploughed under by colonialism owe it to our ancestors, ourselves, and future generations not to trample the rich African heritage by forgetting, silencing, and letting it fall out of history, given the Westernisation of Africans. 
The argument of this article is structured as follows: First, the article highlights the rationale for decolonising biblical interpretation in Africa. The argument is that decolonisation is required on two fronts: (a) those with an African identity who are socially located in Africa tend to read through Western eyes, so we must beware of Westernised African eyes; (b) the current postcolonial environment still retains structures of coloniality which continually destabilises Africa, so we must beware of Westernised Africa. The failure to decolonise African eyes consequently leads to the duplication of WesternEuropean environments in our African context and the perpetuation of coloniality in our current environment. Second, the article suggests the vhufa (heritage) approach to reading Scripture as a way of overcoming coloniality and as a way of bringing African knowledge systems to shape the reading of the biblical text. Third, the vhufa approach is applied to Psalm 82 to show how this approach can be applied to the reading of the biblical text.

\section{Rationale for Decolonisation: Westernised Africans' Eyes and Westernised Africa}

In his "Rereading the Bible with African Eyes: Inculturation and Hermeneutics," Justin Ukpong calls upon African Christians and African biblical scholars to overcome their tendency to read the Bible through the Western interpretive grid. ${ }^{2}$ Ukpong suggests what he terms 'inculturation hermeneutics' as an alternative approach to reading the Bible. The central concern of Ukpong's inculturation hermeneutics is to derive the biblical message/gospel message/theological meaning from the text and to apply that message/ meaning into the African socio-cultural context. For Ukpong, the central aim is "the actualisation of the theological meaning of the text in today's context so as to forge integration between faith and life, and engendered commitment to personal and societal transformation." 3 The means of drawing the theological message out of the text remain largely dependent on established Western exegetical tools. Ukpong's inculturation hermeneutics, inasmuch as it sought to overcome the tendency to use the Western grid, still leaves us with two crucial issues to contend with: first, Westernised African eyes, or what is commonly referred to as the colonised African mind, and second, the structures of coloniality in which Africa as a social location is still entangled. Hence comes the need for African biblical scholars to engage in a hermeneutic that restores the dignity of African people and engages with the biblical text from the perspective of colonial difference.

\section{Westernised African Eyes}

The success of the colonial system relied on and continues to rely on beguiling those who are located in the subaltern regions to think epistemically as do those who are on the hegemonic side. ${ }^{4}$ Europeans conveyed knowledge to the colonised "in a partial and selective way, in order to co-opt some of the dominated into their own power institutions." 5 This process, in turn, led many of the colonised to aspire to be culturally transformed, that is, to

\footnotetext{
Ukpong, "Rereading the Bible with African Eyes," 4.

Justin S Ukpong, "Developments in Biblical Interpretation in Africa: Historical and Hermeneutical

Directions," in The Bible in Africa: Transactions, Trends, and Trajectories. Edited by Gerald O West and

Musa W Dube; Leiden: Brill, 2000, 11-28:24; "Rereading the Bible with African Eyes," 9.

4 Ramón Grosfoguel, "The Epistemic Decolonial Turn," Cultural Studies 2007, 21/2-3:211-223.

5 Anibal Quijano, "Coloniality and Modernity/Rationality,” Cultural Studies 2007, 21/2-3:168-178.
} 
be Westernised. ${ }^{6}$ The so-called African eyes were colonised and are to a large extent Westernised African eyes. As Fanon observes:

Colonialism is not satisfied merely with holding a people in its grip and emptying the native's head of all form and content. By a kind of perverted logic, it turns to the past of the oppressed people, distorts, disfigures and destroys it. This work of devaluing precolonial history takes on a dialectical significance today.

Though colonialism proper is a thing of the past in Africa, yet in the absence of the colonial administration the colonial structures continue to survive, even wearing the face of those who are located on the underside of the colonial matrix of power. Not only does this lead to the duplication, albeit with black faces, of the Western paradigms in our African contexts, but when we choose to retain and uphold the colonial structures and the duplication of Western paradigms, we also run the risk of reproducing their inherent atrocities.

In the South African context decolonisation of the mind should not be viewed only as a project directed toward the black (the previously oppressed), but as a project that is also directed toward the white mind. Realising the damage on the white mind and the injustice inflicted on the black other Snyman argues for the colonial remnants to adopt an ethics of interpretation which is aware of the tendencies of seeking to oppress, violate, marginalise or destroy the other. ${ }^{8}$ For Snyman this can be achieved through hermeneutics of vulnerability and/or epistemic vulnerability as a way of unmasking how issues such as race, gender, sexual orientation, ideologies, prejudices, etc. understand reality and the (biblical) texts. ${ }^{9}$

The recent Rhodes Must Fall campaign has served as an impetus for robust discussion on the decolonisation of the African university. The discussions have gone beyond just removing the statue of a colonial figure, Cecil John Rhodes, from the University of Cape Town to also questioning and challenging the programmes offered, the epistemic foundation of the university and its programme, and the commodification of education (Fees Must Fall campaign), etc. ${ }^{10}$ The African university also serves as an instrument of Western enculturation through the duplication and perpetuation of the Western environment in Africa. African university teachers and students have become intellectual imitators of

6 Quijano, "Coloniality and Modernity/Rationality," 169.

7 See also Sabelo J Ndlovu-Gatsheni, "Global Coloniality and the Challenges of Creating African Futures," Strategic Review for Southern Africa 2014, 36/2:181-202.

8 Gerrie Snyman, "Responding to the Decolonial Turn: Epistemic Vulnerability", Missionalia 2015, 43/3:266-291, http://dx.doi.org/10.7832/43-3-77; Snyman, Gerrie, "The Interpellation of Whiteness: Some Thoughts by a Colonial Remnant reading the Biblical Text”, 2013, 12 September 2016, http://www.interdisciplinary.net/critical-issues/wp-content/uploads/2013/05/G-F-Snyman-Draft-paper.pdf; "Empire and a Hermeneutics of Vulnerability”, Studia Historiae Ecclesiasticae 2011, 37:1-20; “'n Etiek van Bybellees en 'n Hermeneutiek van Weerloosheid", In Die Skriflig/In Luce Verbi 2011, 45/2:259-282; "Social Identity and South African Biblical Hermeneutics: A Struggle against Prejudice", Journal of Theology for Southern Africa 2005, 121:34-55.

9 Snyman writes: "The aim of justice towards the perpetrator is to render him or her vulnerable. In other words, in terms of a decolonial framework, where the effects of colonialism lingers on long after the demise of colonialism itself, the colonisers' offspring who remainsin the colonised territory after the demise of the coloniser and colonisation, is confronted with these effects. They become tainted with colonial perpetration and they are in need of instruments to deal with it. Colonialism exploited the vulnerability of the colonised other and the continuous presence of the coloniser creates a particular vulnerability of its own kind in the face of the execution of justice and restoration". Snyman, "Responding to the Decolonial Turn", 283.

10 See a recent publication Sabelo J Ndlovu-Gatsheni and Siphamandla Zondi, (eds.) Decolonizing the University, Knowledge Systems and Disciplines in Africa. Durham: Carolina Academic Press, 2016. 
Western intellectuals. In highlighting the need to decolonise the African universities, Mbembe states:

They are 'Westernised' in that they are local instantiations of a dominant academic model based on a Eurocentric epistemic canon. An Eurocentric canon is a canon that attributes truth only to the Western way of knowledge production. It is a canon that disregards other epistemic traditions. One that attempts to portray colonialism as a normal form of social relations between human beings rather than a system of exploitation and oppression. $^{11}$

The current pursuit by African universities to be among the highly ranked, world-class universities further perpetuates the Westernisation of Africa, as these African institutions have to offer comparable programmes in the international arena. Such global designs are not innocent, as they serve to embed the colonial matrix of power at a global level. As Escobar argues, "globalisation entails radicalisation of and universality of modernity. No longer purely an affair of the West, however, since modernity is everywhere, the triumph of the modern lies precisely in its having become universal.", 12

\section{Westernised Africa}

Colonialism was more than just a political imposition; it was also about cultural imposition. Colonialism operated among other ways through cultural imperialism, through which African cultures were considered inferior and so were suppressed, negated, and disrupted in order that colonial rule and the racial hierarchies that sustained it may be legitimised. Westernisation in Africa has in some ways penetrated almost every dimension of life family, education, religion, politics, sports, language, and so forth. Colonialism as the imperial machine ensured that no indigenous structure be left untouched by Western systems. In this process African systems were devalued and ploughed under as the Western systems were portrayed and enforced as 'developed' or 'advanced.' The subjugated Africans had not only to adapt to the new rule of colonial empires but also to adopt new systems of life and in many ways also to adapt their ways of living in keeping with the new reality ushered in by the colonial machine.

The Western systems have to a large extent become part of the reality into which we are born, in which we are raised, and in which we continue to live. Maldonado-Torres notes:

Coloniality survives colonialism. It is maintained in books, in the criteria of academic performance, in cultural patterns, in common sense, in the self-image of peoples, in aspirations of self, and so many other aspects of our modern experience. In a way, as modern subjects we breathe coloniality all the time and every day. ${ }^{3}$

Thus, the African eyes through which we see and read remain entrapped within the colonial matrix of power. The colonial values, norms, and ideologies invisibly shape the way we look at our own traditions, cultures, languages and philosophies. Reading the Bible through African eyes requires African biblical scholars to read the Bible from the underside of the colonial matrix of power.

11 Achille Joseph Mbembe, "Decolonizing the University: New Directions", Arts \& Humanities in Higher Education 2016, 15/1:29-45.

12 Arturo Escobar, "Worlds and Knowledges Otherwise: The Latin American Modernity/Coloniality Research Program,” Cultural Studies 2007, 21/2-3:179-210.

13 Nelson Maldonado-Torres, "On the Coloniality of Being: Contributions to the Development of a Concept," Cultural Studies 2007, 21/2-3:240-270. 
The African eyes through which we see need to be rehabilitated from their inclination to privilege the West, that is, their negating of the self by perpetuating Western knowledge systems, literature, histories and culture. Therefore, we need to heed the wisdom of our foremothers when they say, "I shavha $i$ sia muinga $i$ yafhi?" (Running away from your own path, where are you heading?). The call for decolonisation, therefore, is a call to not run away from our own things or our own vhufa (heritage). The deliberate move not to abandon our own heritage is to reject the Western cultural imposition that places Western culture as the universal to which the rest have to adhere. This requires what Ngugi wa Thiongo, Henry Owuor-Anyumba and Taban Lo Liyong regarded as the centring of Africa, that is, "placing Africa at the centre of things, not existing as an appendix or a satellite of other countries and literatures, things must be seen from the African perspective." ${ }^{14}$ This is the subaltern cultures' refusal to be replaced by Western cultures, and it is the basis of the proposal of the vhufa approach to biblical interpretation.

\section{Decolonised Hermeneutics: The Vhufa Approach}

In the aftermath of colonialism in Africa, vhufa (heritage) is commonly associated with preservation and conservation - the attempt to protect and to keep up the cultural and natural heritage in the face of the continuing threat of alienation of indigenous people from their own cultures and from nature. This protection and conservation tends to be of interest to the tourism industry and to archivists. We need to insist on viewing the preservation of our African heritage, both cultural and natural, as a restorative process and as a living process. Two Tshivenda proverbs highlight the importance of heritage: $U$ ṇala tsha ndi $u$ lata (To disown what it is yours is a loss), and Thonga ipfi ndo vhada a i pfi ndo doba (A staff is one that you have made yourself, not one which you have picked up).

The reality that Africa has been and is to a large extent Westernised and continues to be so should not breed a sense of hopelessness. In my view, Africans are not irredeemably trapped within colonial structures with no hope of getting out and of thinking outside of the Euro-Western canon. For African biblical scholars to participate meaningfully in the generation of knowledge within their discipline, we need to do so from the perspective of colonial difference, that is, by learning to think from outside of the Euro-Western paradigms, by embracing our own African epistemologies. ${ }^{15}$ Ndlovu-Gatsheni further argues:

For Africa to create genuinely African futures, they have to be predicated on another reason, logic, thought and epistemology capable of enabling economic disobedience to traditional Euro-North American-centric thought and epistemology that enable global coloniality. Only a decolonised being can appreciate the value of indigenous and endogenous knowledge as ideal for the creation of African futures. ${ }^{16}$

14 Ngugi wa Thiong'o, Henry Owuor-Anyumba and Taban Lo Liyong, "On the Abolition of the English Department" in Homecoming: Essays on African and Caribbean Literature, Culture and Politics, (ed.) Ngugi wa Thiong'o; London: Heinemann, 1972:145-150.

15 African biblical scholars have a role to play in overcoming the colonial damage to the African mind, to Africa as our home and to Africans as residents of the global village. As Ndlovu-Gatsheni argues, "the challenge facing Africans is how to undo this imperial/colonial epistemological damage as part of their drive to create decolonial futures" (Ndlovu-Gatsheni, "Global Coloniality and the Challenges of Creating African Futures," 195).

16 Ndlovu-Gatsheni, "Global Coloniality and the Challenges of Creating African Futures," 196-97. 
From a position of colonial difference, the approach that I am proposing is what I would like to refer to as the vhufa approach. Vhufa is a Tshivenda word, which can be translated as 'heritage.' Vhufa comes in various forms - culture, tradition, artefacts, knowledge systems, religious systems, history, and more. Vhufa is commonly associated with the past. However, vhufa is in this case broadly understood to include the present as a site of creating heritage through knowledge production, lived experiences, new traditions, and so on; it also includes the future, as the present leaves something for the next generation. Vhufa is something of the past, the present, and the future. Thus, in the vhufa approach, African proverbs, riddles, legends, folk tales, songs and philosophy, as well as the African experiences under colonialism and the current post-colonial situation, are taken as resources useful for understanding and interpreting our world as a text and any other text, including the biblical text. I now proceed to outline the broad strokes for reading through the vhufa approach:

First, the vhufa approach is a deliberate move to delink epistemically from the EuroWestern paradigms. I am indebted here to Mignolo, who refers to 'epistemic delinking' as a "a delinking from the web of imperial/modern knowledge and from the colonial matrix of power." 17 To delink is to deny the universality of Euro-Western and to assume no obligation to mimic them in our social location. ${ }^{18}$ The delinking process avoids the trap of ignorance or denial of the existence of the other. The acknowledgement of the existence of the other does not have to imply the denial of the self. The delinking process is the recognition of the Euro-Western paradigms as the other, what I would like to refer to in my own vernacular language as thonga ye munwe a vhada (a staff which another has made). To delink is to believe in one's own ability to carve one's own staff ( $u$ divhadela thonga yau). It does not imply that African biblical scholars cannot learn and draw from others; however, we do not have to do so out of a sense of inferiority or in an attempt to remain within the Euro-Western canon of thought to appease the West. The delinking process is the initial step, not the final step.

Second, the vhufa approach is a process of 'relinking' with the African ancestors and their heritage. The delinking from Euro-Western paradigms without a relinking would create a vacuum, and if unfilled with an alternative knowledge production system, that vacuum would be re-filled with such Euro-Western paradigms as would make the latter condition worse than the former. ${ }^{19}$ The idea of a relinking is an epistemological reorientation that refuses to abandon the rich heritage of our African ancestors. Therefore, it is necessary to familiarise our African minds with our own African systems as an act of decolonising our African minds from the colonial mindset, which tend to privilege EuroWestern knowledge systems. As a Guinea proverb puts it, Knowledge is like a garden, if it is not cultivated, it cannot be harvested. It is when we are familiar with our knowledge systems that such knowledge would inform our readings of the biblical text.

\footnotetext{
17 See Walter D Mignolo, "Delinking: The Rhetoric of Modernity, the Logic of Coloniality and the Grammar of De-Coloniality," Cultural Studies 2007, 21/2-3:449-514; "Epistemic Disobedience, Independent Thought and Decolonial Freedom,” Theory, Culture \& Society 2009:26/7-8, 2009:159-181.

18 To delink is to refuse to regard a particular ethnicity (body politics), that is the European/white, which is located in a particular place on the planet (geo-politics), and its knowledge systems (epistemic politics) as universal. Mignolo, "Delinking," Cultural Studies 2007, 21/2-3:449-514.

To use the biblical words of Jesus, "When an evil spirit comes out of a man, it goes through arid places seeking rest and does not find it. Then it says, 'I will return to the house I left.' When it arrives, it finds the house unoccupied, swept clean and put in order. Then it goes and takes with it seven other spirits more wicked than itself, and they go in and live there. And the final condition of that man is worse than the first" (Mat 12:43-45 NIV).
} 
In line with its orientation which is opposed to both colonialism and coloniality, the vhufa approach takes as its preferential option the damned, the ex-colonised - that is, "the wretched of the Earth," whose postcolonial context is still marked by the life-denying realities of landlessness, poverty, civil war, death, and life as refugees in camps, and whose knowledge systems are, among other things, undermined. ${ }^{20}$ To a large extent, the situation of damnation is a characteristic of the ex-colonised in the current world system, which is racially hierarchised, patriarchal, capitalist, politically hierarchised, and Euro-Americacentric.

The following steps are essential to biblical text analysis using the vhufa approach:

\section{Points of Contact}

As a biblical reader approaches the text allowing his/her African knowledge systems, culture, religious traditions, and experiences to shape his/her reading of the biblical texts, there will certainly be points of contact at which the reader would like to engage the text further. This cannot be determined by a set of rules, as there is fluidity that depends on those particular points of contact at which the reader would choose to engage.

The reader has to determine one or more perspectives that will be useful in the analysis of the text. African proverbs, folk tales, songs, poems, legends, cultural elements, philosophy, religious elements and traditions, lived experience past and present are all useful tools of analysis of the biblical text. The reader can utilise a proverb or folk tale or any other element as an analytical tool. Multiple tools may be utilised to analyse the biblical text.

Having determined the perspective of analysis, it is the prerogative of the reader first to understand the critical point of analysis as gleaned from the analytical perspective. The questions below are useful in determining the usefulness of the critical points of analysis:

- What is the analytical perspective? In other words, what is its point?

- What critical areas of life are addressed by the analytical perspective?

- What can be deduced or what implications can be drawn from the analytical perspective?

\section{Critical Appropriation of African Conceptual Resources and of the Biblical Text}

The utilisation of our African knowledge, culture, religious traditions, and lived experience systems does not imply a blind and uncritical acceptance of ideologies embedded in our $v h u f a$ (heritage), neither does it imply uncritical appropriation of the biblical text. The vhufa approach, like the bosadi approach, critiques both the 'heritage' and the 'text.' The heritage is not innocent, just as the biblical text is also not innocent. To use Maluleke's words, the vhufa approach is about "mature appropriation of past and present forms of African culture." ${ }^{21}$ As Masenya reminds us through her bosadi (womanhood) approach, African culture also includes oppressive elements which are not worth perpetuating; rather, they have to be rejected and resisted. ${ }^{22}$ In the vhufa approach, the biblical reader retains a level

20 Maldonado-Torres, "On the Coloniality of Being," 259-60.

21 Tinyiko Maluleke, "African Culture, African Intellectuals and the White Academy in South Africa - Some Implications for Christian Theology in Africa," Religion and Theology 1996, 31/1:19-42.

22 Madipoane Masenya (Ngwan'a Mphahlele), How Worthy is the Woman of Worth? Rereading Provers 31:10-31 in African-South Africa. New York: Peter Lang, 2004; "Redefining Ourselves: A Bosadi (Womanhood) Approach," Old Testament Essays 1997, 10/3:439-448. 
of suspicion given the oppressive ideologies that can be found both in 'heritage' and in the biblical text, which in a sense is also a heritage, a 'heritage' from outside.

\section{Engagement with the Biblical Text}

On the basis of what the reader is able to determine from the critical points of analysis, he/she utilises the tool of analysis to engage the biblical text at multiple levels, taking into consideration the logic of the biblical text being analysed and using the following interpretive questions: When, why, and how did a particular event or text arise in the first place? What did the event or text mean in its given context? How is it is related or linked with other events and texts? These questions are not owned by anyone - they are basic questions which even our African ancestors have been asking, generation after generation, as they attempted to make sense of reality as a text.

\section{Engagement with the Contemporary Issues}

The goal of the vhufa approach is to explain and to understand the text through an African epistemic lens in our contemporary context. The value of our African epistemic lenses lies in their potential function as tools of analysis which also have the potential to address contemporary issues from the perspective of faith, inasmuch as we believe that the Bible, an ancient text, has the potential to speak to us to our contemporary issues. Through the vhufa approach, we get a double dose in our reading of the text - a dose of our heritage and a dose of biblical text (a faith heritage).

Below we proceed to read Psalm 82 through Africanised eyes via the vhufa approach.

\section{A Vhufa Reading of Psalm 82}

In this section, we would like to re-read Psalm 82 in light of the African sense of justice for the poor and oppressed. The folktale of "The Great Fall of the Tortoise" is regarded here as an example of African sense of justice for the damned or the wretched of the earth. The story goes as follows:

Long, long ago, as our foremothers (makhulukuku) and those who first settled in the land (vhontengu-wa-kugala) have related to us, apart from the animals and the birds on earth, there were other animals on another planet, which was high up in the heavens. The place was so far away that only the birds knew these other animals because they were the only ones who could fly to this other world.

At some point there was drought in the whole land. Many of the animals died owing to lack of water in the rivers and the streams. The animals who lived in the other world sent out a message to the animals on earth, saying, "You who are on earth, if you are able to come to our place, we will feed you and give you water so that you will not die of hunger and thirst."

The birds came together at the great tower. While they were still waiting for those who might have delayed, the tortoise arrived and also expressed its misery from hunger and thirst, although it was not able to fly. The tortoise pleaded with the birds to come up with a plan to take it along to the other world.

The birds agreed to take the tortoise along, and so each bird gave a feather, and the feathers were planted on the tortoise so that he tortoise could fly along with the birds to the other planet. As the tortoise was different from the others, the birds gave the tortoise a new name, All-of-You. 
When they arrived there at the other planet, the citizens of that planet were happy to receive their guests, and they said: "We are so happy that you also came with your king." The birds in one voice answered, "All-of-You."

The citizens of the other planet prepared a meal, and when they were done, they brought the food out to where the birds and their king were. The birds asked, "Who is this food for?" The answer was, "All of you." When the tortoise heard them say, "All of you," it rushed ahead of everyone and ate all the food, leaving only a little for the birds.

The birds did not want to show their disappointment to the residents of the other world at what had just happened. The birds just ate the leftovers of "King All-ofYou." The birds were so angry with the tortoise, though, that when the time came to leave, they did not even say goodbye to it. Instead, each bird took from the tortoise its feather which had made it possible for it to reach that heavenly place. The tortoise was left without feathers and so had the challenge of returning to the earth.

Of all the birds, only tshiruxwe (the parrot) remained behind, and the tortoise requested that when the parrot returned to the earth, it would tell the tortoise's wife to put straw on the tower so that when the tortoise fell to the earth it would not get hurt. The parrot agreed to do so.

However, the parrot had also been disappointed with the tortoise's behaviour, so when it arrived on the earth, it told the tortoise's wife to add more stones on the tower and to make it more solid so that when the tortoise came back, it would be able to land well on the tower. The hardworking wife indeed solidified the tower, and it was very solid.

When the tortoise came down from heaven, it landed in such a way that its shell was severely cracked - cracks everywhere. Even today the shell of the tortoise is still cracked. Even today the injuries of the tortoise cannot be completely healed, even though the wife tried to attend to them.

I first came across the story of the great fall of the tortoise while going through some of the knowledge systems of my own cultural group, the Vhavenda people - the myths, stories, folktales, riddles, sayings, and proverbs. I also found this story in Chinua Achebe's Things Fall Apart, which was published in $1959 .{ }^{23}$ Barbara Harlow regards Achebe's use of the story of the great fall of the tortoise as an example of resistance literature. She sees in the use of the folktale "political significance and an allegory for an African strategy of in-

23 Chinua Achebe's rendition of this story does differ here and there from the Venda rendition. In Chinua Achebe's version, the tortoise is presented as a trickster. This in line with the way the tortoise is often portrayed in the folktales of the Yoruba people. In Achebe's rendition, the trickster deceives the birds on a number of occasions: First, the tortoise, previously known for its deception and self-interest, presents itself as a changed character and therefore deserving to be taken along to the other world. Secondly, the tortoise tricks the birds by insisting that they all get new names, which they will use when they arrive in the other world. Thirdly, the tortoise acts as a representative of the birds and speaks eloquently, which pleases the birds. Fourthly, the tortoise, having assumed the role of representative or king, when the food is presented is quick to ask, "For whom have you prepared this feast?" The reply is, "All of you," at which point the tortoise turns to the birds and says, "You remember that my name is All of You. The custom here is to serve the spokesman first and the others later. They will serve you when I have eaten." In this rendition, the trickster inflicts injustice on the birds; however, the birds also find a way of paying back the trickster for its act of injustice in withholding food from them. Things Fall Apart, New York: Anchor Books, 1959. 
dependence." ${ }^{24}$ Harlow notes that "the writers and critics writing within the context of organised resistance movements comprehend the role of culture and cultural resistance as part of the larger struggle for liberation." 25 This role continues in the post-colonial period aluta continua (the struggle continues). Reading the Bible in the post-colonial era is to participate in an uncompleted struggle for liberation in an environment which continues to perpetuate consciously or unconsciously the suppression of African forms of knowledge and cultures, and the exploitation of non-Western lands and their people. ${ }^{26}$ Moreover, culture and cultural resistance form part of a struggle against oppressive elements in an environment of suppression and exploitation that is perpetuated by those with black faces. The repossession of our heritage ( $v h u f a$ ), thus, has to serve as a decolonial strategy against oppression and exploitation from imperialism and any other current form of oppression and exploitation within our own legitimate structures.

The language used in African folktales such as the one reproduced above is not strictly literal, in which our ancestors were narrating events in the animal realm. Instead, it is metaphoric, describing human reality. In its utilisation of metaphoric language, African folklore speaks indirectly and ironically, with the intention of instilling right values and morals in the audience; it is also intended to be heard by those criticised. In this story, the animal behaviour functions as a mirror of human behaviour, and the main reference in the story is to human beings, not animals in and of themselves. Thus, not only do the African stories in which the animals are the key role players open the world of reality from which they arose (not the animal reality but the human reality), they also serve to project a possible world.

Inasmuch as the folklore of interrogation may be viewed as anticolonial, resisting foreign domination, such folklore may also function as a tool of resistance against oppression and exploitation from legitimate powers. Therefore, the following critical points are discernible with regard to justice:

- First, the masses have the right to expect their leaders to act justly towards them, to enable them to access opportunities through which they can improve their livelihood and so escape poverty and starvation.

- Second, those in position of power ought to see that the masses have enabled them to be in such positions so they would serve the masses, not simply their own selfinterests.

- Third, when those in position of power fail to administer justice through acts of greed, the masses have the right to withdraw their support for such leaders as an act of administering justice.

It can therefore be argued that the story of the great fall of the tortoise is about administering justice against those in positions of power who fail to address the needs of the poor and the oppressed. In the folktale of our interrogation, the tortoise did not illegitimately assume the position of 'leader' or 'king' or 'representative'; it was granted that position. It was the birds who provided the feathers to enable the tortoise to fly, and it was they who let the tortoise take the leading role on the basis of its smooth tongue. It should be noted, however, that in the Vhavenda culture the tortoise is not the trickster as it is in the

\footnotetext{
24 Barbara Harlow, Resistance Literature, New York: Routledge, 1987:xv.

25 Harlow, Resistance Literature, 10.

26 I am indebted here to Musa Dube, Postcolonial Feminist Interpretation of the Bible, St. Louis: Chalice Press, 2000:19-21.
} 
Yoruba and Fon cultures. Whether the tortoise is regarded as a trickster or not, the point of the story can be said to be that when even legitimate leaders abuse the power granted to them by neglecting the needs of the poor, justice in such cases is served by withdrawing the support and letting such leaders fall. In this story, it is the poor - the victims of a greedy leader (the tortoise) - who administer justice.

Now, turning to the psalm of our enquiry, Psalm 82 is generally considered one of the most overtly mythological texts in the Old Testament. The use of mythological language in Psalm 82, as Human argues, should be viewed as "mirror image of its earthly counterparts. In analogy to realities and descriptions of the earthly world, the heavenly realm, its activities and divine rulers are visualised. This conception of theological analogical thought means that the activities of human beings are equivalent to those of a god, of the gods or of God. Heaven and earth thus share a form of parallel description. What is described about heaven is reflected on earth, and vice versa." ${ }^{27}$ From an African perspective, the use of mythological language in Psalm 82 is welcomed as a way of interpreting human reality.

The mythical language in Psalm 82, as will be argued here, was to express a 'fall' of a great proportion of those in positions of power. Scholars generally agree that Israel took over mythological motifs to express her religious convictions in Yahweh as the one and only God. ${ }^{28}$ This psalm may indeed be one of the key texts reflecting the faith development from polytheism to monotheism within Israel; however, to enclose the understanding of this psalm at this level would be to chase the poor and the oppressed out of this text and to exonerate the perpetrators of injustice. In such an understanding of this text, the suffering of the poor and the oppressed would hence be blamed upon the gods and not upon the human perpetrators. This psalm does not have to be understood as shifting the 'blame' from the human perpetrators of injustice to the 'gods'; that is, it is not saying, "Blame the gods; don't blame the king and his administration."

Psalm 82 as a mirror of human reality can thus be understood as a 'prophetic psalm' which presents a prophetic judgement on behalf of the poor and oppressed. ${ }^{29}$ The poor and the oppressed in Psalm 82, unlike in the folk tale of the Great Fall of the Tortoise, do not act themselves, nor do they administer justice themselves. Instead, they depend upon the divine to administer justice on their behalf. Psalm 82 in its prophetic character takes the matter of injustice against the poor and the oppressed to the highest court of appeal. In this court of appeal YHWH accuses either the judges or the gods of poor administration of

27 Dirk Human, "Psalm 82: God Presides in a Deflated Pantheon to Remain the Sole Just Ruler," in From Ebla to Stellenbosch: Syro-Palestinian Religions and the Hebrew Bible, Abhandlungen des Deutschen Palästinavereins 37, (ed.) Izak Cornelius and Louis Jonker (Wiesbaden: Harrassowitz Verlag), 2008:154-168.

28 See Mark S Smith, The Origins of Biblical Monotheism: Israel's Polytheistic Background and the Ugaritic Texts. Oxford: Oxford University Press, 2003; SB Parker, "The Beginning of the Reign of God - Psalm 82 as Myth and Liturgy," Revue Biblique 1992, 102:532-559, Matitiahu Tsevat, "God and the Gods in Assembly: An Interpretation of Psalm 82," Hebrew Union College Annual 1969-1970, 40-41:123-137; H Wheeler Robinson, "The Council of Yahweh," Journal of Theological Studies 1944, 45:151-157; Jon D Levenson. Sinai and Zion, New York: Harper \& Row, 1987:62; Creation and the Persistence of Evil, Princeton: Princeton University Press, 1994:6.

29 For Seitz, Psalm 82 reflects "scribal prophecy," which reflects a shift in prophetic literature - in this shift, God speaks in the divine council without the need for a prophetic agent. Christopher R Seitz, "The Divine Council: Temporal Transition and New Prophecy in the Book of Isaiah,” Journal of Biblical Literature 1990, 109/2:229-247. For Hilber, the Asaphite Psalms, in particular Pss 50, 75, 81, 82, and 95, should be viewed as cultic prophetic psalms which originated from pre-exilic times onward. John W Hilber, Cultic Prophecy in the Psalms. Berlin: Walter de Gruyter, 2005:128-184. 
justice (cf. Ps 50). ${ }^{30}$ YHWH thus lays the charges just as in the prophetic literature, wherein the prophets employ the lawsuit form in which God lays charges against his people (Deut 32:1-25; Isa 1:2-20; Mic 6:1-8; Jer 2:4-13, 29; Ps 50:1-23). ${ }^{31}$ As Gemser argues regarding the $r \hat{\imath} b$-pattern:

All is ultimately left to, lies in the hands of, the Supreme Judge and Ruler, whose judgement is righteous, but unpredictable, and inscrutable for human understanding, whose ways are not ours. He is a person, not a system or an order. But this implies that there is an appeal to Him, even an irrational, [undeserved,] unjustifiable appeal to his heart, his compassion, his grace. ${ }^{32}$ In the context wherein God himself lays charges, he also acts as judge.

Psalm 82, by setting Elohim as the final court of appeal on behalf of the poor and the oppressed, evokes texts such as Deuteronomy 1:9-17, 16:16, and 2 Chronicles 19:1-9, in which Israel's judicial system is in view. In these texts, the king/leader and his administrators are viewed as instruments of YHWH in the administration of justice because "judgement belongs to God" (Deut 1:17), and "with the Lord our God there is no injustice or partiality or bribery." Therefore, in Psalm 82 Elohim as the one who has granted the judges their responsibility, is portrayed as the one who also has the right to dismiss the appointed judges.

In mythological language the failure to administer justice is presented as a disaster of cosmic proportion that amounts to the reversal of creation to its initial state of darkness, a situation parallel to the shaking of the entire foundation of the earth (v. 5). Thus, failure to administer justice properly on behalf of the poor and the oppressed is to bring creation to a state of collapse. For Elohim the failure to administer justice properly has eventually led to the collapse of society - a complete degeneration of society in which judgement on the perpetrators of injustice has become inevitable. The judgement of the perpetrators of injustice is couched in mythological language to indicate the great proportion of the fall: sons of the Most High will die like mere men and, like every other ruler who has failed in the execution of justice, they will fall (v. 7).

In Psalm 82 Elohim is presented as the judge, so to speak, as one who pulls out the feathers of those who were elevated to positions of such authority and power that they were called "sons of the Most High," which was a title of honour. In human reality, in ancient Israel, it was Israel's king, who as in other ancient Near Eastern cultures was called or declared the 'son' of God (Ps 2:7; 2 Sam 7:14). ${ }^{33}$ Kings in the ancient Near East were the administrators of justice. In the Old Testament the status of King Solomon is enhanced when he is portrayed as a wise administrator of justice (see $1 \mathrm{Kgs} \mathrm{3.3-14,16-28).} \mathrm{For} \mathrm{the}$ Egyptians, the king, as divine or as a quasi-divine being, was responsible for maintaining

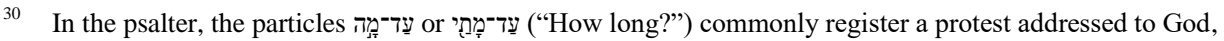
calling upon him to act (Pss 6:3; 74:9, 10; 80:5; 79:5; 9; 89:47; 90:13; 94:3); however, in other places it is YHWH who calls people to account or lays charges (Pss 4:3:50; 58).

31 Herbert B Huffmon, "The Covenant Lawsuit in the Prophets," Journal of Biblical Literature 1959, 78:285-296.

32 B Gemser, "The Rib- or Controversy-pattern in Hebrew Mentality," in Wisdom in Israel and in the Ancient Near East. VTSup 3; (ed.) Martin Noth and D Winton Thomas; Leiden: Brill 1955:120-137.

33 Gerald Cooke, "The Israelite King as Son of God," Zeitschrift für altestamntliche Wissenschaft 1978, 90:202-225; "The Sons of (the) God(s)," Zeitschrift für altestamentliche Wissenschaft 1964, 76:22-47; Herman Gunkel, Introduction to the Psalms (trans.) Joachim Begrich; Macon: Mercer University Press, 1998:106-109; Adela Yarbro Collins and John Joseph Collins, King and Messiah as Son of God: Divine, Human, and Angelic Figures in Biblical and Related Literature. Grand Rapids: Eerdmans, 2008.
} 

order, justice and political stability in society. ${ }^{34}$ In Mesopotamia, Hammurabi praised himself as follows: "I am indeed the shepherd whose sceptre is just. My benevolent shade was spread over my city. I held the people of the lands of Sumer and Akkad safely on my lap." In the Law Code of Hammurabi he is commissioned by the divine pantheon to "cause justice to prevail in the land, to destroy the wicked and evil, that the strong might not oppress the weak" (prologue, 2:31). Thus, the Israelite kings, just as did other kings in the ancient Near East, had a responsibility to administer justice and to protect the poor, weak and oppressed in society. However, in Psalm 82, the Israelite kings had failed to live up to this ideal of being just shepherds, by allowing the unjust and the wicked to thrive at the expense of the poor and weak.

In the context of the psalter as whole, Psalm 82 anticipates the fall of the Davidic monarchy in Psalm 89. The "sons of the Most High" or 'gods' in Psalm 82 were supposed to have administered God's justice by defending the weak and the fatherless, maintaining the rights of the poor and the oppressed; all these are virtues which were expected of the Davidic kings as the chief administrators of justice (see Ps 72; cf. Isa 11:3-5). It should be noted, however, that the poor and oppressed who suffered at the hands of their rulers were not seeking for justice in the other world; rather, they were seeking justice in their lived experiences. The mere assertion of YHWH as the only God would not have meant justice in their lived experiences unless such justice was administered in their own social-political situation. For the poor and oppressed with whom this prophetic psalm is concerned, the only form of justice on their behalf would have to be the fall of their ruler(s). In the Psalter it is the Davidic king who will "fall like any other ruler," justice thereby being served to the poor and oppressed of Israel. It is in Psalm 89 that the father-son covenantal relationship between God and the Davidic kings is reported to be broken, resulting in the covenant being renounced and the crown defiled in the dust (Ps 89:39). ${ }^{35}$ The breaking of the covenant by the Davidic kings resulted in Elohim, as the chief administrator of justice in Israel, pulling the feathers out from the Davidic tortoise and letting it fall to the ground, to the dust. For the Davidic crown to be defiled in the dust was a symbol of the king being dethroned. For Wilson the fall of the Davidic kingship in Psalm 89 eventually led to the replacement of hope in the Davidic rulers to hope in the enduring kingship of Yahweh. ${ }^{36}$ While Wilson's attempt to make sense of the plot is open to criticism, he does highlight a significant shift within the hypothetical 'plot' of the psalm. ${ }^{37}$ Important for us to note is that

34 JG Manning, "The Representation of Justice in Ancient Egypt," Yale Journal of Law \& Humanities 2012, 24/1:111-118.

35 In the biblical narrative, the dust formula was also used as an act of enthroning, that is, an elevation to kingship (Gen 2:7; 1 Sam 2:6-8; 1 Kgs 16:2-3; Ps 113:7). See Walter Brueggemann, "From Dust to Kingship (1 Kings 16:2; Genesis 3:19)," Zeitschrift für altestamentliche Wissenschaft 1972, 84:1-18; "Remember, You Are Dust," Journal for Preachers 1991, 14/2:3-10.

36 See Gerald H Wilson, The Editing of the Hebrew Psalter. SBLDS 76; Chico: Scholars Press, 1985; "King, Messiah, and the Reign of God: Revisiting the Royal Psalms and the Shape of the Psalter," in The Book of Psalms: Composition and Reception (ed.) Peter W Flint and Patrick D Miller Jr.; Leiden: Brill, 2000:391-406; "The Structure of the Psalter" in Interpreting the Psalms: Issues and Approaches (ed.) David G Firth and Philip S Johnston; Downers Grove: InterVarsity Press, 2005:229-46.

37 Wilson's argument has been challenged by others; see among others David C Mitchell, The Message of the Psalter: An Eschatological Programme in the Book of the Psalms. JSOTSup 206; Sheffield: Sheffield Academic Press, 2007:78-83; David M Howard Jr., "Recent Trends in Psalms Study," in The Face of Old Testament Studies: A Survey of Contemporary Approaches, (ed.) DW Baker and B Arnold; Grand Rapids: Baker, 1999:329-368; Roger N Whybray, Reading the Psalms, JSOTSup 222; Sheffield: Sheffield Academic Press, 1996:93-98. 
in the context of the psalm, the failure of the Davidic rulers to administer justice on behalf of the weak and fatherless, the poor and oppressed, eventually led to the collapse of the Davidic kingdom.

In the South African context, in 1994 the colonial-apartheid tortoise that robbed the indigenous people of their land and set up systems that benefited the white minority finally fell from its lofty place to the ground, thereby making way for South Africa to be the last state to gain its independence from colonial regime in Africa. The colonial-apartheid tortoise was a brutal, illegitimate white supremacist force that imposed itself upon the African land, dispossessing the African beings of their land, racially oppressing and discriminating against them socially and economically.

The dawn of democracy in South Africa implied that for the first time, the black masses had the right put their feathers in whomever they deemed fit to deliver on the promise for a just society by undoing the colonial-apartheid racialised social and economic patterns in order to create a better life for all. Since 1994 the majority of South African people have put their feathers on the African National Congress to lead government in the five consecutive national elections (1994, 1999, 2004, 2009, 2014). While there have been many gains achieved under the current democratically elected tortoise, there are still many in South Africa living in extreme poverty, this while the political elites and their cronies enrich themselves through patronage and corruption. The poor and the marginalised of this society are left to wonder how long the current tortoise will continue to feed itself at their neglect and leave them to pick up the crumbs from under the table. The interests of the poor and oppressed and the weak and fatherless are neglected as the political elites and their cronies seek to protect their own stomachs and self-interests.

Just as Asaph in Psalm 82 imagined a day of reckoning on the unjust kings, the poor and oppressed and the weak and fatherless of the present look forward to the day of reckoning on their legitimate, democratically elected leaders.

In 2011, following the South African government's refusal to grant the Dalai Lama a visa to South Africa to attend the birthday celebration of Bishop Desmond Tutu, out of anger and frustration Tutu addressed the current tortoise: "One day we will be praying for the defeat of the ANC government... Watch out, ANC government. Watch out!" While Tutu's frustration and anger may be justified, it cannot compare to the frustration and the anguish of the poor masses through whose feathers those in power fly. South Africa's recent local government election, held in August 2016, has proven the power of the citizenry to pull their feathers off the tortoise because of continued disappointment with the current leadership. The citizenry pulled the economic feathers from the African National Congress, evidenced by its failure to win outright the key metropolitan areas and its loss of some other metropolitan areas.

The story of the great fall of the tortoise and Psalm 82, inasmuch as they are laments in the face of injustice against the poor and oppressed and the weak and fatherless, are also stories of the administration of justice. Moreover, they highlight other important dimensions in the execution of justice. First, the poor and the oppressed can also function in and of themselves as administrators of justice. The birds in our folktale in their dissatisfaction with the greedy conduct of the tortoise did not regard themselves as weak vessels who had no authority or power. It was through their feathers that the tortoise had made it to the other planet, and so they had the right to withdraw their feathers. The withdrawal of the feathers by all the birds shows a sense of communal justice served upon those who serve in positions of power in society. In a democratic environment such as ours in South Africa, in which the poor and the suffering continue to linger in poverty while the political elites 
continually enrich their pockets and the country becomes one the most unequal countries in the world, the poor and the suffering becoming more conscious of the power they have in administering justice for themselves.

Second, the story of the great fall of the tortoise should also serve as a reminder of the individual role that each individual has in the administration of justice. In the story, tshiruxwe (the parrot) did not immediately leave when the other birds had all pulled out their feathers from the tortoise, who was probably thinking that it would outsmart the birds again. The tortoise, realizing that the only way for him to get back to the earth was going to be through falling down, requested the parrot to pass a message to the tortoise's wife to prepare the landing place for a soft landing. The parrot, however, would not have it that the tortoise gets away with injustice by having a safe landing, and it therefore ensured that justice would be served. Thus, the story of the great fall of the tortoise also serves as a reminder that individuals, as well as leaders have a role to play in the administration of justice on behalf of the poor and the suffering.

In Psalm 82, it is YHWH, or God, who as chief administrator of justice, exercises judgement on behalf of the poor against the oppressors and perpetrators of injustice by dethroning them from their position of power. However, from the African perspective, the divine also acts through human agency. In the context of Israel, it was first Assyria as his rod, and then Babylon as his rod. In the African context, the poor and the suffering should also regard themselves as custodians of justice. In the context of democracy, the poor and suffering have the right to protest and withdraw their support when their dignity is undermined through exploitation and corruption by those in power. The democratic right to vote grants the masses the right to pull their feathers out from those who do not administer justice and to trust others with their feathers.

\section{Conclusion}

Reading the Bible with awareness of the colonial damage done to Africans and Africa, and awareness of the persistent structures of coloniality, calls for a hermeneutical re-orientation. In this, article I have suggested a vhufa approach as one way which in which African biblical scholars utilise African knowledge systems in shaping their hermeneutical lenses in their reading of the biblical text. In so doing, African biblical scholars choose to venerate their own ancestors and so play the biblical drum to their own tune, rather than simply playing the biblical drum to the Western tune.

\section{BIBLIOGRAPHY}

Achebe, Chinua 1959. Things Fall Apart. New York: Anchor Books.

Brueggemann, Walter 1991. "Remember, You Are Dust." Journal for Preachers 14/2:3-10.

Brueggemann, Walter 1972. "From Dust to Kingship (1 Kings 16:2; Genesis 3:19)." Zeitschrift für altestamentliche Wissenschaft 84:1-18.

Collins, Adela Yarbro and Collins, John Joseph 2008. King and Messiah as Son of God: Divine, Human, and Angelic Figures in Biblical and Related Literature. Grand Rapids: Eerdmans.

Cooke, Gerald 1978. "The Israelite King as Son of God.” Zeitschrift für altestamntliche Wissenschaft 90:202-225. 
Cooke, Gerald 1964. The Sons of (the) God(s)." Zeitschrift für altestamentliche Wissenschaft 76:22-47.

Dube, Musa 2000. Postcolonial Feminist Interpretation of the Bible. St. Louis: Chalice Press.

Escobar, Arturo 2007. "Worlds and Knowledges Otherwise." Cultural Studies 21/2-3:179-210.

Gemser, B 1955. "The Rib- or Controversy-pattern in Hebrew Mentality." Pages 120-137 in Wisdom in Israel and in the Ancient Near East. Vetus Testamentum Supplement 3. Edited by Martin Noth and D Winton Thomas. Leiden: Brill.

Grosfoguel, Ramón 2007. "The Epistemic Decolonial Turn.” Cultural Studies 21/2-3:211-223.

Gunkel, Herman 1998. Introduction to the Psalms. Translated by Joachim Begrich. Macon: Mercer University Press.

Harlow, Barbara, 1987. Resistance Literature. New York: Routledge.

Hilber, John W 2005. Cultic Prophecy in the Psalms. Berlin: Walter de Gruyter.

Howard, David M Jr. 1999. "Recent Trends in Psalms Study." Pages 329-368 in The Face of Old Testament Studies: A Survey of Contemporary Approaches. DW Baker and B T Arnold (eds.). Grand Rapids: Baker.

Huffmon, Herbert B 1959. "The Covenant Lawsuit in the Prophets." Journal of Biblical Literature 78:285-296.

Human, Dirk 2008. "Psalm 82: God Presides in a Deflated Pantheon to Remain the Sole Just Ruler." Pages 154-168 in From Ebla to Stellenbosch: Syro-Palestinian Religions and the Hebrew Bible. Abhandlungen des Deutschen Palästina-vereins 37. Edited by Izak Cornelius and Louis Jonker. Wiesbaden: Harrassowitz Verlag.

Levenson, Jon D 1994. Creation and the Persistence of Evil. Princeton: Princeton University Press.

Levenson, Jon D 1987. Sinai and Zion. New York: Harper \& Row.

Masenya, Madipoane (Ngwan'a Mphahlele) 2004. How Worthy is the Woman of Worth? Rereading Provers 31:10-31 in African-South Africa. New York: Peter Lang.

Masenya, Madipoane (Ngwan'a Mphahlele) 1997."Redefining Ourselves: A Bosadi (Womanhood) Approach.” Old Testament Essays 10/3:439-448.

Maluleke, Tinyiko 1996. "African Culture, African Intellectuals and the White Academy in South Africa - Some Implications for Christian Theology in Africa.” Religion and Theology 31/1:19-42

Maldonado-Torres, Nelson 2007. "On the Coloniality of Being: Contributions to the Development of a Concept." Cultural Studies 21 /2-3:240-270.

Manning, JG 2012. "The Representation of Justice in Ancient Egypt." Yale Journal of Law \& Humanities 24/1:111-118.

Mbembe, Achille Joseph 2016. "Decolonizing the University: New Directions.” Arts \& Humanities in Higher Education 15/1:29-45

Mignolo, Walter D 2007. "Delinking: The Rhetoric of Modernity, the Logic of Coloniality and the Grammar of De-Coloniality." Cultural Studies 21/2:449-514.

Mignolo, Walter D 2009. "Epistemic Disobedience: Independent Thought and Decolonial Freedom” Theory, Culture \& Society 26/7-8:159-181. 
Mitchell, David C 2007. The Message of the Psalter: An Eschatological Programme in the Book of the Psalms. JSOT Sup 206. Sheffield: Sheffield Academic Press.

Ndlovu-Gatsheni, Sabelo J and Zondi, Siphamandla (eds.) 2016. Decolonizing the University, Knowledge Systems and Disciplines in Africa. Durham: Carolina Academic Press.

Ndlovu-Gatsheni, Sabelo J 2014. "Global Coloniality and the Challenges of Creating African Futures." Strategic Review for Southern Africa 36/2:181-202.

Ngugi wa Thiong'o, Henry Owuor-Anyumba and Taban Lo Liyong 1972. "On the Abolition of the English Department" in Homecoming: Essays on African and Caribbean Literature, Culture and Politics. Edited by Ngugi wa Thiong'o. London: Heinemann.

Parker, SB 1992. "The Beginning of the Reign of God - Psalm 82 as Myth and Liturgy." Revue Biblique 102:532-559.

Quijano, Anibal 2007. "Coloniality and Modernity/Rationality." Cultural Studies 21/2-3:168-178.

Robinson, H Wheeler 1944. "The Council of Yahweh.” Journal of Theological Studies 45:151-157.

Seitz, Christopher R 1990. "The Divine Council: Temporal Transition and New Prophecy in the Book of Isaiah." Journal of Biblical Literature 109/2:229-247.

Smith. Mark S 2003. The Origins of Biblical Monotheism: Israel's Polytheistic Background and the Ugaritic Texts. Oxford: Oxford University Press.

Snyman, Gerrie 2005. 'Social Identity and South African Biblical Hermeneutics: A Struggle against Prejudice', Journal of Theology for Southern Africa 121:34-55.

Snyman, Gerrie 2011. "Empire and a Hermeneutics of Vulnerability." Studia Historiae Ecclesiasticae 37:1-20.

Snyman, Gerrie 2011. 'n Etiek van Bybellees en 'n hermeneutiek van weerloosheid.'In Die Skriflig/In Luce Verbi 45:259-282.

Snyman, Gerrie 2013.'The Interpellation of Whiteness: Some Thoughts by a Colonial Remnant reading the Biblical Text', http://www.inter-disciplinary.net/criticalissues/wp-content/uploads/2013/05/G-F-Snyman-Draft-paper.pdf.

Snyman, Gerrie 2015. "Responding to the Decolonial Turn: Epistemic Vulnerability." Missionalia 43/3:266-291, http://dx.doi.org/10.7832/43-3-77.

Tsevat, Matitiahu 1969-1970. "God and the Gods in Assembly: An Interpretation of Psalm 82.” Hebrew Union College Annual 40-41:123-137.

Ukpong, Justin S 1995. "Rereading the Bible with African Eyes: Inculturation and Hermeneutics.” Journal of Theology for Southern Africa 19:3-16.

Ukpong, Justin S 2000. "Developments in Biblical Interpretation in Africa: Historical and Hermeneutical Directions." Pages 11-28 in The Bible in Africa: Transactions, Trends, and Trajectories. Edited by Gerald O West and Musa W Dube. Leiden: Brill.

Whybray, Roger N 1996. Reading the Psalms. JSOT Sup 222; Sheffield: Sheffield Academic Press.

Wilson, Gerald H 2005. "King, Messiah, and the Reign of God: Revisiting the Royal Psalms and the Shape of the Psalter." Pages 391-406 in The Book of Psalms: 
Composition and Reception. Edited by Peter W Flint and Patrick D Miller Jr. Leiden: Brill.

Wilson, Gerald H 1985. The Editing of the Hebrew Psalter. SBLDS 76; Chico: Scholars Press.

Wilson, Gerald H 2005. "The Structure of the Psalter." Pages 229-246 in Interpreting the Psalms: Issues and Approaches. Edited by David G Firth and Philip S Johnston. Downers Grove: InterVarsity Press. 